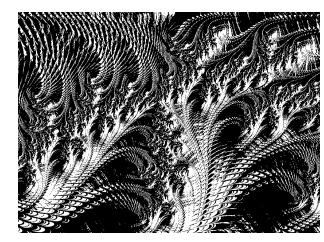

https://doi.org/10.5559/di.30.3.03

\title{
THE MEDIATING ROLE OF TEACHER_PUPIL INTERACTION IN THE RELATIONSHIP OF PUPIL TEMPERAMENT TO SELF-ESTEEM AND SCHOOL SUCCESS
}

Slavica ŠIMIĆ ŠAŠIĆ, Ana ŠIMUNIĆ, Mira KLARIN University of Zadar, Zadar, Croatia

UDK: 373.3.064.2:159.923.4(497.5+497.6)

Original scientific paper

Received: November 26, 2019

The aim of this research was to examine the mediating role of teacher-pupil interaction in the relationship of temperament to self-esteem and school success among year-7 and year-8 elementary-school pupils in Croatia and Bosnia \& Herzegovina (B\&H). The assumptions on the contribution of the dimensions of temperament (self-control and negative affectivity) and teacher-pupil interaction (influence and proximity) in explaining pupils' self-esteem and school success were partially confirmed. Similar relationships among the measured variables were confirmed in both samples of pupils. Self-control, negative affectivity, and teacher proximity directly predicted self-esteem, while self-control indirectly predicted self-esteem through teacher proximity. Self-control and teacher proximity contributed directly to school success, and the indirect contribution of self-control to school success through teacher proximity was also significant. The results of this research indicate the importance of the direct contribution of children's temperaments to their self-esteem and school success, and of its indirect contribution through the quality of the interaction with their teacher.

Keywords: teacher-pupil interaction, temperament, self-esteem, school success

Slavica Šimić Šašić, University of Zadar, Department of Teacher and Preschool Teacher Education, Franje Tuđmana 24i, 23000 Zadar, Croatia. 
According to Bronfenbrenner's theory of ecological systems, the development and psychosocial adaptation of a child should be observed within the given context (Bronfenbrenner \& Morris, 2006). Development is a result of the interaction of a child's characteristics with the context. The teacher, as part of the microsystem, affects the behaviour of the child. The Model of Interpersonal Behaviour of Teachers (Wubbels et al., 1993) emphasises that teaching is a form of communication, and that the way teachers convey content while teaching affects their relationships with pupils. The concept of circularity in the model implies that changes in one part of the system lead to changes in another; i.e. teacher behaviour influences pupil behaviour and vice versa. The relationship and interaction the teacher achieves with pupils in the classroom depend partly on the pupils' characteristics, such as their temperaments. Rothbart (2004) believes that the characteristics of one's temperament stimulates reactions in others that can either increase or decrease the risk of developing problems.

\section{The relationship of temperament to self-esteem and school success}

One of the leading temperament theories today is that developed by Rothbart (2007), who defines temperament as the individual differences in the nervous system's emotional, motor, and attention-linked reactivity, and in self-regulation, which modulates reactivity. The author cites three (earlier four) key dimensions of temperament: extraversion/surge (positive affectivity: includes activity, low shyness, high intensity of pleasure, impulsiveness, positive anticipation, affinity); negative affectivity (includes anger/frustration, fear, discomfort, sadness, reduced reactivity); and self-control (effortful control involving attention control, inhibitory control, perceptual sensitivity, low intensity of comfort). Self-esteem is a sociopsychological construct that relates to individual attitudes and perceptions of self-worth (McMullin \& Cairney, 2004). The classical view is that the self-esteem of a person is influenced by significant others. According to the cognitive ('bottom-up') model, evaluative feedback (success or failure, interpersonal acceptance or rejection) affects self-evaluations, which determine the feeling of self-worth and general self-esteem. The affective model ('top-down') assumes that self-esteem develops early in life as a result of temperament and relationships with significant others (Brown \& Marshall, 2006). Once formed, it affects self-evaluations and feelings of self-worth. For example, high self-esteem promotes, protects, and restores the feeling of self-worth (Brown \& Marshall, 2006). Research on behavioural genetics 
DRUŠ. ISTRAŽ. ZAGREB GOD. 30 (2021), BR. 3, STR. 509-531

ŠIMIĆ ŠAŠIĆ, S. ET AL.: THE MEDIATING ROLE... emphasises that some interindividual differences in self-esteem can be explained by genetic factors (Robins et al., 2010). The integration of these two approaches assumes that genetically-conditioned individual differences relate to how people are perceived by significant others, and how a person perceives their social and physical environment. These person-environment transactions are a powerful source of self-esteem (Robins et al., 2010). Klein (1992) reports that flexibility (adaptability), attention, and reactivity are positively associated with self-esteem. Robins et al. (2010) found that adolescents with high self-esteem showed greater levels of effortful control, while Heinonen et al. (2002) stated that difficult temperament in adolescents aged 12 was associated with lower self-esteem at age 18. Hintsanen et al. (2010) found that self-esteem was positively associated with perseverance, while it was negatively associated with emotionality.

School success is an important outcome of formal education, having implications not only for continuing education and professional development, but also for overall psychological development (e.g., self-concept, mental health, etc.). Studies confirm the correlation between effortful control, as a dimension of temperament, and school success (Al-Hendavi, 2015; Duckworth \& Allred, 2012). Generally, it has been shown that poorer academic performance correlates with lower task orientation (poor attention and persistence, high distractibility) and, to a lower extent, with higher levels of activity and lower levels of approachability (Teglasi et al., 2004). Effortful control serves to reduce emotional distress that limits cognitive resources required for learning, planning, solving problems, and goal-directed behaviour. Thus, effortful control positively predicts adaptation and school performance. For example, following directions and maintaining attention helps pupils focus on tasks and prevent distractions (Hernández et al., 2017).

\section{The relationship of teacher-pupil interaction to self-esteem and school success}

A positive interaction between teachers and pupils, high in warmth and low in conflict, correlates with pupils' academic beliefs, motivation, performance, and self-esteem (Cornelius-White, 2007; Roorda et al., 2011; Šimić Šašić, 2012, 2017). Šimić Šašić (2012) found that pupils' self-esteem and school success correlated more highly with teacher behaviour in a positive interaction, with the 'best' teacher, than in a negative interaction, with the 'worst' teacher. In the first case, pupils' self-esteem correlated positively with teachers' leadership, helping, and understanding, and negatively with teachers' insecurity, 
DRUŠ. ISTRAŽ. ZAGREB GOD. 30 (2021), BR. 3, STR. 509-531
ŠIMIĆ ŠAŠIĆ, S. ET AL.: THE MEDIATING ROLE...

dissatisfaction, conflict and strictness. School success correlated positively with teacher helping and understanding, and negatively with teacher dissatisfaction. In a negative interaction, with the 'worst' teacher, self-esteem did not correlate with any teacher behaviour, and school success correlated only with teacher strictness, negatively. When the teacher-pupil interaction was presented through two dimensions - the dimensions of influence and proximity - pupil self-esteem and school success only correlated with teacher proximity when interacting with the 'best' teacher. Nelson (1984) similarly concludes that teacher involvement, support, order and organisation, and innovation correlates positively with pupil self-esteem, while teacher control correlates negatively with pupil self-esteem. Close relationships with the teacher improve pupils' academic and social skills (Hamre \& Pianta, 2006) by providing a secure basis for pupils to learn about socially appropriate behaviour, academic expectations, and how to achieve them, and thus indirectly enhances their self-esteem (Martin, 2014).

\section{The relationship between temperament and teacher-pupil interaction}

Research results confirm the relationship between pupil temperament and teacher-pupil interactions (McClowery et al., 2013; Rothbart \& Bates, 2006; Rudasill \& Rimm-Kaufman, 2009). Pupils with low persistence in tasks, high activity, and high negative reactivity have a negative interaction with the teacher and are more likely to disrupt classroom activities, while pupils with a high level of task persistence are more likely to experience a positive relationship with the teacher. Pupils with low levels of activity and negative reactivity, but a high level of task persistence, are found to be competent and easy to teach, receive more positive feedback, and need less monitoring (McClowery et al., 2013; Rothbart \& Bates, 2006; Rudasill \& Rimm-Kaufman, 2009). Rudasill (2011) conducted a longitudinal study in which she measured the characteristics of children's temperaments and the quality of teacher interaction in preschool, and in years 1 and 3. Lower shyness and aggressiveness and greater effortful control of pupils were associated with a positive teacher-pupil relationship. In the sample of pupils in the first and third years of primary school, she found that a lower level of effortful control is associated with a more conflicting and less close relationship with the teacher. She also found that pupils in year 3 had lower levels of effortful control and a more conflicting teacher relationship, because of a more conflicting relationship with the year- 1 
DRUŠ. ISTRAŽ. ZAGREB GOD. 30 (2021), BR. 3, STR. 509-531

ŠIMIĆ ŠAŠIĆ, S. ET AL.: THE MEDIATING ROLE... lationship quality. It seems that the quality of early teacherpupil relationships has implications for the quality of later relationships, and that the quality of these relationships depends partly on the characteristics of pupils, such as temperament. Such relationships indicate that the teacher-pupil interaction may be a mechanism by which pupil temperament influences learning outcomes.

\section{The mediating role of teacher-pupil interaction}

According to a model presented by Eisenberg et al. (2010), the teacher-pupil relationship (among others) mediates the relationship between pupils' effortful control (as dimensions of temperament) and academic competence. Effortful control (directing and shifting attention, inhibitory and activation control, and planning) affects the quality of teacher-pupil relationships. The teacher-pupil relationship affects pupils' engagement in class activities and motivation (attending school or avoiding it, participation in class activities, work habits), which ultimately affect academic competence (academic achievement, grades, class attendance). The model was tested by Hernández et al. (2017), who found that effortful control positively predicts proximity and negatively predicts conflict in teacherpupil relationships. Pupil effortful control also indirectly predicted better school success through greater teacher-pupil proximity. Klein (1992) believes that temperament actually affects self-esteem by influencing the ability of children to meet the demands of the environment and adapt to the expectations of parents, peers, and teachers, which is in line with the integrative transactional approach.

\section{The role of cultural context}

Research shows that temperament (Ahadi et al., 1993; Gaias et al., 2012), the quality of teacher-student interaction (Beyazkurk \& Kesner, 2005; den Brok \& Levy, 2005), self-esteem (Chan, 2000; Tashakkori, 1993), and school success (Eng et al., 2008; OECD, 2014) show dependence on the broader cultural context. These differences are most often explained by differences in socialisation, which arise from different value systems. The cultural context (macrosystem) influences the development of an individual directly, but also indirectly by influencing the characteristics of significant others (values, attitudes). The characteristics of significant others shape relationships and interactions with children, and affect the characteristics of children (Adams \& Ryan, 2005; Darling \& Steinberg, 1993). Previous research has shown some differences among adolescents in Croatia and B\&H that may indicate cultural differences in socialisation. Young people in $\mathrm{B} \& \mathrm{H}$ are more engaged 
DRUŠ. ISTRAŽ. ZAGREB GOD. 30 (2021), BR. 3, STR. 509-531

ŠIMIĆ ŠAŠIĆ, S. ET AL.: THE MEDIATING ROLE... in family interactions (Klarin et al., 2012b), and their parents have greater influence on decision-making in various spheres of life (Klarin et al., 2010), as well as a greater contribution from family interaction (family satisfaction and family loneliness) to explaining self-esteem (Klarin et al., 2012a). Radin (2002) found a change in value orientations of young people in Croatia towards individualism, as well as differences in value orientations with regard to regional affiliation. Young people in B\&H show greater orientation towards collectivism than young people in Croatia (Šimić Šašić \& Klarin, 2014; Puhalo, 2005). However, considering the relative importance of each of the four dimensions of culture (vertical/individual individualism/collectivism), no differences were found in the sample of primary-school pupils from Zadar (Croatia) and Čitluk and Ljubuški (B\&H) (Šimić Šašić \& Klarin, 2014). Since Čitluk and Ljubuški are populated mainly by Croatians (Tadić, 2019), the similarities in the cultural patterns of these two environments seem understandable. At the country level, there are also some differences in the education systems. In addition to the duration of primary school education (8 years in Croatia and 9 years in $\mathrm{B} \& \mathrm{H})$, in B\&H there are three curricula: the Curriculum in the Republic of Srpska, the Framework Curriculum of the Federation of $\mathrm{B} \& \mathrm{H}$, and the Curriculum for Teaching in the Croatian Language (Ibrahimović, 2015). Pupils in Citluk and Ljubuški attend a nine-year primary school programme according to the Curriculum for Teaching in the Croatian Language.

The aim of this study was to examine the potential mediating role of the quality of the teacher-pupil interaction in the relationship between pupil temperament and self-esteem and school success among year-7 and year-8 elementary-school pupils in Zadar (Croatia) and in Čitluk and Ljubuški (B\&H). Due to both the similarities and the differences established in previous research among pupils from the two countries, we decided to test the models separately for each sample, but we set up a null hypothesis. Since research shows that the quality of the teacher-pupil interaction differs according to the subject taught by the teacher (Levy et al., 1993), we decided to ask the pupils to assess the interaction with their Croatian-language teacher (the subject they spend most time studying) and their average grade in this subject (as an indicator of school success). The specific problems of this research were: a) to determine whether the pupils in these two samples differ in their temperament, perception of teacher-pupil interaction quality, self-esteem, or school success (school grade in the Croatian-language subject), b) examine whether teacherpupil interaction mediates the relationship of pupil temperament 
DRUŠ. ISTRAŽ. ZAGREB GOD. 30 (2021), BR. 3, STR. 509-531

ŠIMIĆ ŠAŠIĆ, S. ET AL.: THE MEDIATING ROLE..

(1) FIGURE 1

Display of the suggested (hypothesised) model of the relationship between pupil temperament, teacher-pupil interaction, and student self-esteem / school success

Pupil temperament to pupil self-esteem and school success in these two samples; and c) identify possible differences in the relationship of pupil temperament and teacher interaction to self-esteem and school success in these two samples of pupils. The hypothesis was that there were no differences in the measured variables among students in the two different countries (a). Pupils with positive temperament characteristics (greater self-control and lower negative affectivity) were expected to have a more positive interaction (greater proximity and influence) with the teacher, meaning that temperament would contribute indirectly to higher pupil self-esteem and better school success through positive teacher-pupil interaction. In addition, it was assumed that the positive characteristics of a pupil's temperament would contribute directly to higher self-esteem and better school success regardless of the relationship with the teacher (partial mediation) (b). The hypothesised model is shown in Figure 1. Significant differences in the relationships of these variables according to the two pupil samples were not expected (c). Testing the hypotheses using samples from two different countries contributes to validating the proposed model of the relationships among the measured variables.

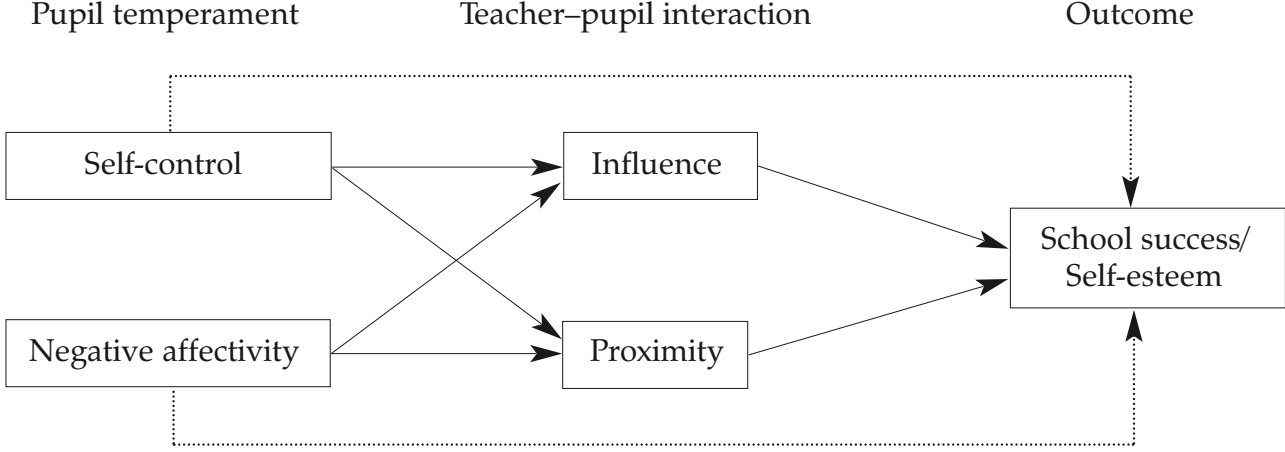

Note: The dotted lines represent the hypothesised partial mediation of teacher-pupil interaction: that is, the additional direct contribution of pupil temperament to explaining variance in the dependent variable.

\section{METHOD}

\section{Participants}

The research was conducted using a convenience sample of year-7 and year-8 pupils at one primary school in Zadar (Croatia, $N=189)$, one in Citluk and one in Ljubuški (B\&H, $N=294)$. There were 252 male and 225 female pupils in the sample (with 6 pupils not answering the question on gender). The ratio of boys and girls in both samples was similar. The pupils were 
DRUŠ. ISTRAŽ. ZAGREB GOD. 30 (2021), BR. 3, STR. 509-531

ŠIMIĆ ŠAŠIĆ, S. ET AL.: THE MEDIATING ROLE... aged $12-16$, and the average age was 13.40 years. Pupils from Croatia were slightly older $(t=2.19 ; p=0.03 ; M C R=13.49$; $M B H=13.35)$. This was probably a result of differences between the education systems. Children who attend year 1 of elementary school must be 6 years old before September 1st in B\&H, but before April 1st in Croatia. The samples differed according to their place of residence $\left(\chi^{2}=267.23, p=0.00\right)$. Most pupils from Croatia lived in the city $(96.1 \%)$ while the majority of pupils from B\&H lived in rural areas (87\%). Pupils in the two countries also differed in the education of their parents. The parents (mothers and fathers) in Croatia had higher levels of education than those in $\mathrm{B} \& \mathrm{H}\left(\chi^{2}=61.13, p=0.00\right.$; $\left.\chi^{2}=45.92, p=0.00\right): 48.9 \%$ of mothers and $49.72 \%$ of fathers in Croatia had only completed high school $(63.03 \%$ of mothers and $53.96 \%$ of fathers in $\mathrm{B} \& \mathrm{H})$, while $38.46 \%$ of mothers and $36.16 \%$ of fathers in Croatia had completed higher education (12.68\% of mothers and $17.63 \%$ of fathers in $\mathrm{B} \& \mathrm{H})$. In $\mathrm{B} \& \mathrm{H}$, there were more unemployed mothers $\left(\chi^{2}=28.18, p=0.00\right.$; B\&H $48.78 \%$, Croatia $24.47 \%$ ), while differences in the unemployment of fathers were not statistically significant $\left(\chi^{2}=0.57\right.$, $p=0.45 ; \mathrm{B} \& \mathrm{H} 25.43 \%$, Croatia $22.35 \%$ ).

\section{Measures}

The Early Adolescent Temperament Questionnaire (Ellis \& Rothbart, 2001) - adapted by Macuka (2012) on a sample of Croatian pupils. Temperament dimensions of self-control and negative affectivity were used in this study. The dimension of self-control includes subscales of attention (capacity to direct and drift attention), activation control (the capacity to perform an action when there is a strong tendency to avoid it), and inhibitory control (the ability to plan and control inappropriate responses). The scale consists of 13 items, e.g. "If I have to do a difficult task, I begin immediately". The coefficients of internal reliability (Cronbach alpha) among pupils in Croatia and $\mathrm{B} \& \mathrm{H}$ are 0.70 and 0.64 . The dimension of negative affectivity includes subscales of anger and fear that describe irritability, anger, or frustration, i.e., the intensity of negative affect associated with the interruption of goal achievement, and the level of fear, i.e., unpleasant affects connected with the anticipation of stress (Macuka, 2012). This scale consists of 13 items, e.g. "It bothers me when I want to make a phone call, and the phone line is busy". Cronbach alpha coefficients in the Croatian and B\&H samples were 0.75 and 0.74. Pupils were asked to estimate how much each of the statements in the questionnaire related to them on a five-point scale: 1 , almost always false; 2 , mostly false; 3 , sometimes false / sometimes true; 4, mostly true; 5, almost always true. The total score for each subscale is calculated on the basis of the average score 
DRUŠ. ISTRAŽ. ZAGREB GOD. 30 (2021), BR. 3, STR. 509-531

ŠIMIĆ ŠAŠIĆ, S. ET AL.: THE MEDIATING ROLE...

1 Influence $=$

$(0.92$ lea $)+(0.38$ hel $)$ -

0.38und) - (0.92res) -

(0.92unc) - (0.38dis) +

(0.38adm) $+(0.92 \mathrm{str})$ and proximity $=$

$(0.38$ lea $)+(0.92$ hel $)+$

0.92 und + (0.38res) -

(0.38unc) - (0.92dis) -

$0.92 \mathrm{adm})-(0.38 \mathrm{str})$

(Wubbels \& Brekel-

mans, 2005).

\section{Procedure}

on the associated items. A higher score indicates greater self-control and a higher level of negative affectivity.

Questionnaire on Teacher Interaction (Wubbels \& al., 1993) adapted by Šimić Šašić (2012) on a sample of Croatian pupils - consists of 48 items, measuring eight teacher behaviours: leadership (lea), helping/friendly (hel), understanding (und), student responsibility/freedom (res), uncertain (unc), dissatisfied (dis), admonishing (adm), and strict (str). Coefficients of internal consistency range from 0.76 to 0.90 in the Croatian sample, and from 0.72 to 0.82 in the B\&H sample. Examples of items are: "The teacher is a good leader" (Leadership); "The teacher helps us with our work" (Helping). Pupils were asked to estimate how often their Croatian-language teacher behaved in a certain way on a five-point scale, where 1 means never, 2 rarely, 3 sometimes, 4 often, and 5 always. Weighting results ${ }^{1}$ on individual subscales makes it possible to express individual scores on two dimensions: those of influence and proximity. The dimension of influence (dominance/submissiveness) indicates who manages or controls communication and how often, while the dimension of proximity shows the degree of cooperation and closeness among participants in communication. A higher score indicates greater influence and greater proximity/closeness of teachers in interacting with pupils.

Self-Esteem Scale (Vizek-Vidović \& Kuterovac-Jagodić, 1996) was constructed in line with the Rosenberg Self-Esteem Scale. It refers to the assessment of self-worth and reflects the degree of concurrence or non-concurrence of the real value (child's real opinion of itself) and the desired value (how the child would like to be). The scale has 12 items (e.g.: "I have a lot of good qualities", Cronbach alpha 0.88), in which pupils are required to assess their level of agreement using a five-point scale (1, strongly disagree, to 5 , always agree). The total score is calculated on the basis of the average score on the associated items. A higher score indicates higher self-esteem.

Data on school grades in the Croatian-language subject: the pupils in this study assessed their interaction with the Croatian-language teacher (Croatia $N=4, \mathrm{~B} \& \mathrm{H} N=8$ ) and reported their school grades in the Croatian language as an indicator of the learning outcome. A school grade scale of 1 (unsatisfactory) to 5 (excellent) is used in both countries.

The research was conducted with the permission of the principals and professional service of the schools, and with the consent of the pupils' parents. The questionnaire was applied by professional associates at the school. Pupils completed a questionnaire during regular school lessons (approximately 
15 minutes being needed to complete the questionnaire), near the end of the school year (May). Participation of the pupils was voluntary and anonymous.

\section{RESULTS}

(1) TABLE 1

Descriptive statistics and correlations (Croatia below the diagonal, B\&H above) between the variables in the two samples of pupils
The descriptive statistics and correlations between the variables among pupils in Croatia and $\mathrm{B} \& \mathrm{H}$ are displayed in Table 1. Differences in dimensions of temperament, quality of interaction between teachers and pupils, pupil self-esteem and school grades in the Croatian language between these two samples were tested using the $t$-test. There was no statistically significant difference between the two groups of pupils in self-control, assessment of teacher influence, pupil self-esteem and school grades in the Croatian language. However, $\mathrm{B} \& \mathrm{H}$ pupils reported a higher level of negative affectivity $(t=4.29$, $p=0.00$ ) and evaluated teachers as more close and willing to cooperate with them $(t=-4.08, p=0.00)$ than Croatian pupils.

\begin{tabular}{|c|c|c|c|c|c|c|c|c|c|c|}
\hline & \multicolumn{2}{|c|}{ Croatia } & \multicolumn{2}{|c|}{$\mathrm{B} \& \mathrm{H}$} & \multirow[b]{2}{*}{1} & \multirow[b]{2}{*}{2} & \multirow[b]{2}{*}{3} & \multirow[b]{2}{*}{4} & \multirow[b]{2}{*}{5} & \multirow[b]{2}{*}{6} \\
\hline & $M$ & $s d$ & $M$ & $s d$ & & & & & & \\
\hline 1 Self-control & 3.37 & 0.62 & 3.44 & 0.55 & 1.00 & -0.01 & $0.20^{* *}$ & $0.26^{* *}$ & $0.43^{* *}$ & $0.29^{* *}$ \\
\hline 2 Negative affectivity & 3.02 & 0.69 & 3.31 & 0.67 & -0.05 & 1.00 & -0.08 & -0.13 & $-0.17^{*}$ & -0.07 \\
\hline 3 Influence & 1.83 & 1.64 & 1.77 & 1.66 & $0.25^{*}$ & -0.08 & 1.00 & -0.07 & 0.09 & -0.03 \\
\hline 4 Proximity & 2.99 & 4.18 & 4.37 & 3.03 & $0.32^{* *}$ & -0.10 & 0.14 & 1.00 & $0.28^{* *}$ & $0.26^{* *}$ \\
\hline 5 Self-esteem & 3.82 & 0.84 & 3.84 & 0.74 & $0.39 * *$ & $-0.39^{* *}$ & $0.25^{*}$ & $0.44^{* *}$ & 1.00 & $0.25^{* *}$ \\
\hline 6 School success & 3.93 & 1.01 & 3.83 & 1.04 & $0.44^{* *}$ & 0.07 & 0.16 & $0.22^{*}$ & 0.12 & 1.00 \\
\hline
\end{tabular}

${ }^{* *} p<0.01 ;{ }^{*} p<0.05$

Correlation analyses (Table 1) showed that the self-esteem of the Croatian pupils is associated positively with pupil self-control, teacher influence and proximity, and negatively with pupils' negative affectivity. Croatian-language school grade was positively associated with pupil self-control and teacher proximity. In $\mathrm{B} \& \mathrm{H}$, self-esteem and school grade in the Croatian language showed the same pattern of correlations with the measured variables, except for the correlations with teacher influence.

Further analyses sought to test the hypothesised model shown in Figure 1 for its goodness of fit to the data obtained (model fit). More specifically, models of the contribution of pupil temperament (self-control and negative affectivity) to school success (grade in the Croatian-language subject) and self-esteem through the influence and proximity of teachers were tested. The model was tested for each separate country and criterion, which means that two models were tested on the basis of the criteria (self-esteem and school success) for two groups of pupils (Croatian and Bosnian). 
DRUŠ. ISTRAŽ. ZAGREB GOD. 30 (2021), BR. 3, STR. 509-531

ŠIMIĆ ŠAŠIĆ, S. ET AL.: THE MEDIATING ROLE...
The models and the significance of indirect contributions were estimated by conducting multi-group path analysis and using the program Mplus 6.12 (Muthen \& Muthen, 1998-2010), with the ML (maximum likelihood) method of parameter estimation. Before the analysis, the absence of extreme multivariate combinations of results was determined by calculating Machalanobis's distances for each subject and the linearity of the relationships between variables was determined by inspecting scatterplots. Negative affectivity and self-control on the one hand, and influence and proximity on the other, were considered relatively independent components of pupil temperament and teacher-pupil interaction. In testing the models, direct relationships between temperament and self-esteem and school success (dotted lines in the hypothetical model in Figure 1 - partial mediation hypothesis) were tested against a model without these relationships (full mediation). Equality settings or constraints of certain sets of parameters (path coefficients and correlations) in the models across the two samples did not lead to significant deterioration of model fit, meaning that it is legitimate to test the models for the entire sample. Therefore, the models tested for the entire sample are displayed and further interpreted in this paper. The chi-square difference test was used to compare the full and partial mediation models. The partial mediation models (self-esteem: $\chi^{2}=0.709 ; d f=1$; $p=0.3997$; school success: $\left.\chi^{2}=0.713 ; d f=1 ; p=0.399\right)$ fit the data significantly better than the full mediation models (self-esteem: $\chi^{2}=67.273 ; d f=3 ; p=0.000$; school success: $\chi^{2}=29.216$; $d f=3 ; p=0.000)$ for both self-esteem $\left(\Delta \chi^{2}=66.564 ; d f=2 ; p=\right.$ $0.000)$ and school success $\left(\Delta \chi^{2}=28.503 ; d f=2 ; p=0.000\right)$ as output variables.

Fit indices of the final solution of the models are shown in Table 2, while Figures 2 and 3 are representations of these models with standardised estimates of parameters. Only paths with a significance level lower than $p=0.05$ are presented, for the sake of simplifying the model displays. Standardised parameter estimates of the size and significance of the indirect contributions assumed by the model, with previously determined testing requirements, are presented in Table 3.

The following indices of model fit were used to estimate the models: chi-square $\left(\chi^{2}\right)$ and SRMR (standardised root-mean-square residual) as indices of absolute fit, RMSEA (root-mean-square error of approximation) as an Index of parsimony, and TLI (Tucker-Lewis Index) and CFI (comparative fit Index) as comparative indices. A statistically insignificant $\chi^{2}$ value implies that the variance and covariance matrix of the sample $(S)$ is equal to the population matrix $(\Sigma)$, and that the model fits the data (Brown, 2006). All other indices also point to an 
() TABLE 2

Fit indices of the final solution of the model of relationships between pupil temperament, characteristics of teacherpupil interactions, and school success / self-esteem of pupils in Croatia and B\&H

Models

adequate degree of suitability or correct fit of models to the data (the criteria for acceptable model fit proposed by $\mathrm{Hu}$ and Bentler (1999) being: RMSEA $\leq 0.06 ; S R M R \leq 0.08 ; C F I \geq 0.95$; $T L I \geq 0.95)$. Therefore, it can be said that the final solutions of the tested models show very good fit to the data obtained (Table 3).

\begin{tabular}{|c|c|c|}
\hline Indices of absolute fit & $\begin{array}{r}\text { Indices of parsimony } \\
R M S E A\end{array}$ & Comparative indices \\
\hline$\chi^{2} / d f / p \quad S R M R$ & (90\% CF interval) & CFI TLI \\
\hline
\end{tabular}

\begin{tabular}{lrllll}
$\begin{array}{l}\text { 1. Output variable: } \\
\text { Self-esteem } \\
\text { multigroup }\end{array}$ & $\begin{array}{r}1.106 / 2 / 0.575 \\
\text { CRO-0.009 } \\
\text { B\&H-1.098 }\end{array}$ & 0.012 & $0.000(0.000-0.126)$ & 1.000 & 1.052 \\
$\begin{array}{l}\text { Self-esteem } \\
\text { without } \\
\text { grouping }\end{array}$ & $0.709 / 1 / 0.400$ & 0.009 & $0.000(0.000-0.133)$ & 1.000 & 1.017 \\
$\begin{array}{l}\text { 2. Output variable: } \\
\text { School success } \\
\text { multigroup }\end{array}$ & $\begin{array}{r}1.107 / 2 / 0.575 \\
\text { CRO-0.009 }\end{array}$ & 0.012 & $0.000(0.000-0.126)$ & 1.000 & 1.087 \\
$\begin{array}{l}\text { School success } \\
\text { without } \\
\text { grouping }\end{array}$ & B\&-1.098 & & & & \\
\hline
\end{tabular}

\begin{tabular}{lrrrr} 
Relations & Estimate & $\begin{array}{r}\text { Standard } \\
\text { error }\end{array}$ & Est./S.E. & $p$ \\
\hline Self-control $\rightarrow$ Proximity $\rightarrow$ Self-esteem (All pupils) & 0.053 & 0.017 & 3.128 & 0.002 \\
Self-control $\rightarrow$ Proximity $\rightarrow$ School success (All pupils) & 0.045 & 0.019 & 2.358 & 0.018 \\
\hline
\end{tabular}

(1) TABLE 3

Standardised estimates and level of significance of the indirect contribution of pupil temperament (self-control) to self-esteem / school success through teacher-pupil interaction (teacher proximity) shown in the models in Figures 2 and 3 for the entire sample of pupils
The models tested on the data from all pupils explain $27 \%$ of the variance of self-esteem (model c in Figure 2) and 15\% of the variance of school success (model c in Figure 3). A higher level of pupil self-esteem was predicted by a higher level of self-control and lower level of negative affectivity of pupils, and by greater proximity of the teacher. Also, higher levels of pupils' self-esteem were indirectly predicted by their own self-control through the increasing proximity of teachers (model c in Figure 2; Table 4). A higher level of school success was predicted by greater pupil self-control and greater proximity of the teacher, but not by negative affectivity. Moreover, higher grades in the Croatian-language class were indirectly predicted by the pupils' self-control through an increase in teacher proximity (model c in Figure 3; Table 4). Teacher influence had no significant value in predicting pupil self-esteem / school success in any of these cases, but greater teacher influence was significantly predicted by greater pupil self-control (model c in Figures 2 and 3). 


\section{(1) FIGURE 2}

Model displays with standardised estimates of path coefficients for the relationships between pupil temperament (self-control and negative affectivity), characteristics of teacher-pupil interactions (teacher influence and proximity) and self-esteem

Pupils in Croatia

$0.27^{* *}$

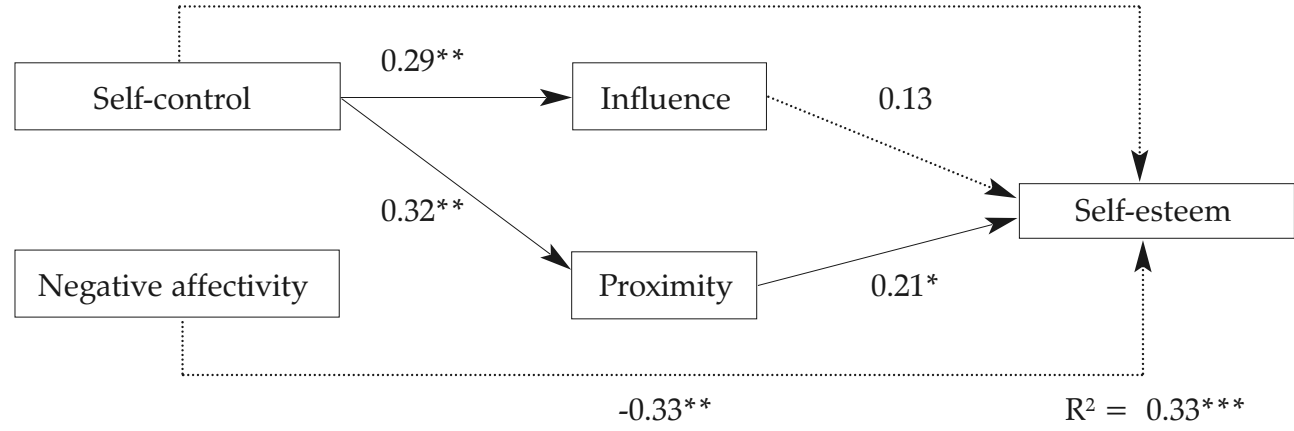

Pupils in B\&H

$0.40^{* *}$

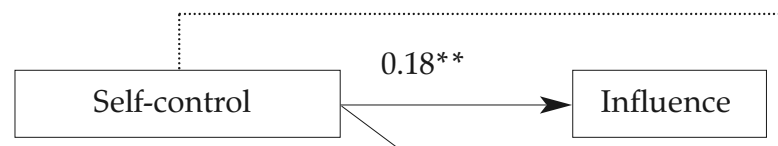

$0.27^{* *}$

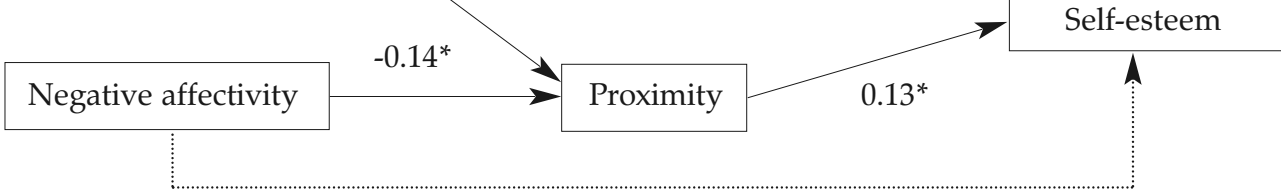
$-0.18^{* *}$
$\mathrm{R}^{2}=0.24^{* *}$

All pupils

$0.35^{* *}$
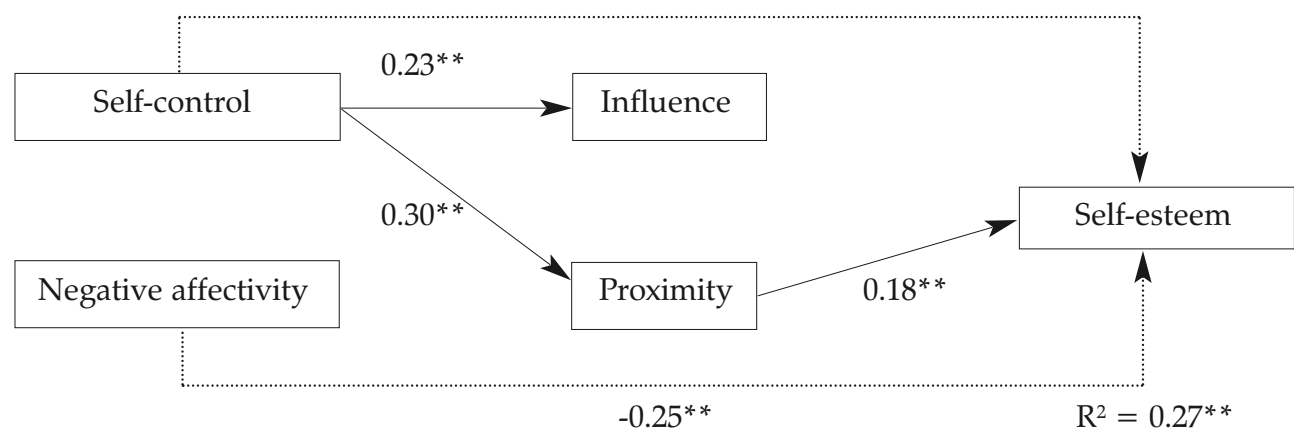

Note: ${ }^{*} p<0.05 ;{ }^{*} p<0.01$ 


\section{(1) FIGURE 3}

Model displays with standardised estimates of path coefficients for the relationships between pupil temperament (self-control and negative affectivity), characteristics of teacher-pupil interactions (teacher influence and proximity), and school success

\section{Pupils in Croatia}

$0.39^{* *}$

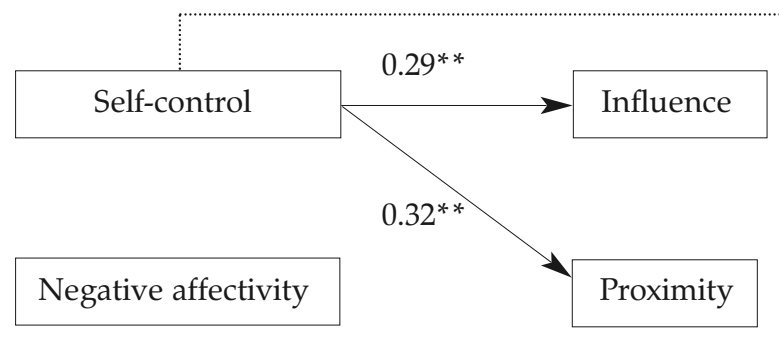

Pupils in B\&H

$0.27^{* *}$

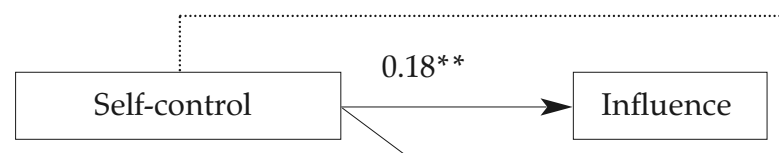

$0.29^{* *}$

School success

$\mathrm{R}^{2}=0.13^{* *}$

All pupils

$0.32^{* *}$

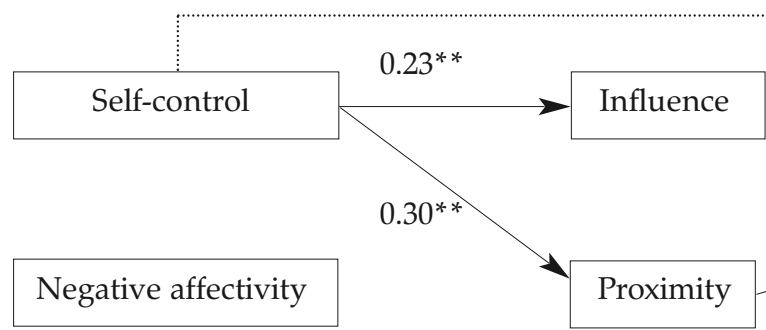

$0.19^{*}$

$$
\mathrm{R}^{2}=0.20^{* *}
$$

School success

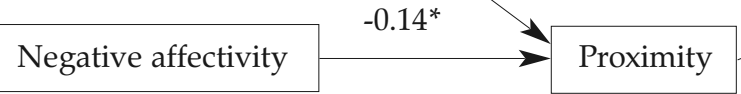

\section{Proximity}

$$
\mathrm{R}^{2}=0.15^{* *}
$$

Note: ${ }^{*} p<0.05 ;{ }^{* *} p<0.01$ 
The pupils in Croatia and B\&H differed in negative affectivity and perception of teacher proximity. The higher level of negative affectivity, and the perception of higher levels of cooperation and proximity of teachers, in B\&H could be attributed to the broader cultural context. Negative affectivity refers to irritability, anger, or frustration, i.e., the intensity of negative affect related to the interruption of goal achievement, and of fear related to the anticipation of stress. It is possible that the difference obtained in negative affectivity between pupils in these two samples is a result of the poorer economic conditions of young people in $\mathrm{B} \& \mathrm{H}$, and of socialisation differences. Some foreign studies have also found cultural differences in negative affectivity. Chinese children, compared with those in the United States (US) (Ahadi et al., 1993), and US children compared with Finnish (Gaias et al., 2012), show a greater level of negative affectivity. The authors explain these results by the greater use of punishment (in China and the US) and the experience of stress in parents (in the US), which may increase the level of negative emotionality in children. In $\mathrm{B} \& \mathrm{H}$, there is a lower gross domestic product, lower wages, higher unemployment, lower purchasing power, and lower level of education of the population (Statistics Agency of B\&H, 2017; Croatian Bureau of Statistics, 2017), which possibly causes a higher level of stress in parents in $\mathrm{B} \& \mathrm{H}$, and a higher level of negative affectivity in children. Previous research has also shown differences in the expression of collectivist and individualistic orientations among adolescents in these two countries (Klarin et al., 2010; Klarin et al., 2012a; Klarin et al., 2012b; Šimić Šašić \& Klarin, 2014; Puhalo, 2005). Previous research has shown that pupils whose families come from collectivist cultures perceive greater teacher proximity (den Brok \& Levy, 2005). Authors explain these differences through differences in value systems, differences in pupils' interpretations of perceived teacher behaviours, and by differences in the treatment of pupils. Beyazkurk and Kesner (2005) concluded that teachers in Turkey showed significantly greater proximity in the relationship with pupils than teachers in the US. The authors explained this through differences in socialisation, emphasising that parents in Turkey (which is a more collectivist-oriented country than the US) may find it important for their children to have a close, positive relationship with teachers at school, while parents in the US view the importance of the relationship with teachers through the importance of school success.

The main aim of this research was to examine the potential mediating role of the quality of teacher-pupil interaction 
DRUŠ. ISTRAŽ. ZAGREB GOD. 30 (2021), BR. 3, STR. 509-531

ŠIMIĆ ŠAŠIĆ, S. ET AL.: THE MEDIATING ROLE... in the relationship between temperament and self-esteem and school success in year-7 and year-8 elementary-school pupils. The models explained a higher percentage of the variance for self-esteem than for school grades in the Croatian language, and a slightly higher percentage of the explained variance of both criteria in the sample of pupils in Croatia. The first conclusion that could be drawn from the results obtained is that high pupil self-control (and low negative affectivity in $\mathrm{B} \& \mathrm{H}$ ) predicts a more positive teacher-pupil interaction (greater teacher influence and proximity), which is consistent with other research findings (McClowery et al., 2013; Rothbart \& Bates, 2006; Rudasill \& Rimm-Kaufman, 2009; Valiente et al., 2012). The better the pupils are at focusing and controlling their attention, and the greater their persistence and inhibitory control (along with a lower intensity of negative affect), the better the teacher is in managing communication and being close with pupils during communication. Teachers consider pupils who are better at regulating their behaviour as 'ideal pupils'; i.e., they find them easier to teach (McClowery et al., 2013). A direct contribution of the dimensions of temperament (greater self-control and lower negative affectivity) and of teacher proximity to pupil self-esteem was also established. As expected, the better the pupils regulate their behaviour and show less negative affectivity, and the closer and more cooperative the teachers are with pupils, the higher the level of pupil self-esteem. Although other authors measured differently conceptualised dimensions of temperament and teacher interaction, similar patterns of relationships between positive and negative dimensions of temperament and teacher interaction and self-esteem have been shown previously (Hernández et al., 2017; Robins et al., 2010; Šimić Šašić, 2012, 2017). The assumption of indirect relationships between temperament and self-esteem through the quality of teacher interaction is only partially confirmed. Self-control indirectly predicted self-esteem through positive contributions to teacher proximity and through positive contributions of proximity to self-esteem. The more self-controlled the pupils are, the closer the teachers are with them, thus enhancing pupil self-esteem.

The temperament and quality of the teacher-pupil interaction showed weaker links to school success (expressed by the assessment of school grades in the Croatian language). Self-control and proximity of teachers made a direct contribution to the success of pupils in the Croatian language (among the pupils from $\mathrm{B} \& \mathrm{H}$ and the entire sample). Pupils who have a greater ability to focus attention and control activation have greater inhibitory control, and, in situations where the teacher 
DRUŠ. ISTRAŽ. ZAGREB GOD. 30 (2021), BR. 3, STR. 509-531

ŠIMIĆ ŠAŠIĆ, S. ET AL.: THE MEDIATING ROLE... cooperates and shows closeness to pupils in the classroom, have better school performance. This finding is in line with the expectations and results of previous research on the relationship of temperament (effortful control, primarily) to school success (Al-Hendavi, 2015; Duckworth \& Allred, 2012; Hernández et al., 2017; Teglasi et al., 2004). It is also in line with findings showing that aspects of the teacher-pupil relationship relate less to school outcomes than behavioural ones (Roorda et al., 2011), and that teachers' empathy and warmth relates mostly to learning outcomes (Cornelius-White, 2007). Moreover, self-control indirectly predicted school success through increased teacher proximity (among the B\&H pupils and the entire sample). When the behaviour of pupils is more self-regulated, the teachers are more likely to be close and cooperative with them, which is linked to better school performance. These findings confirm the assumption of Eisenberg et al. (2010) of social relations as a mechanism through which effortful control is linked to school success. It is easier for teachers to connect with pupils who regulate their behaviour well, since these pupils adjust their behaviour to accord with their peers and with class activities.

The research conducted has certain limitations. A cross-sectional research design was used, so it is not possible to speak of causal relationships between variables. Future research should verify the observed relationships longitudinally. An additional problem is the convenience of samples, which differ in some sociodemographic variables and size. Future research should test the relationships of the observed variables on data from representative samples of pupils in both countries. The potential existence of cultural differences should be examined amongst members of cultures that are mutually more different. There is also the problem of pupil self-assessments, which could have increased the shared variance among variables. Therefore, other sources of information (e.g., parents and teachers) should be included in future research.

The results indicate a need to educate teachers on the impact of pupil temperament and the quality of teacher-pupil interaction on learning outcomes. Teachers should develop sensitivity to the needs of pupils of different temperaments. Increasing teachers' awareness of the impact of temperament in a specific situation may lead to reduced conflict between teachers and pupils and may enable pupils to experience a positive interaction with teachers. On the other hand, pupils need to strengthen self-control and effortful control in order to have a more positive relationship with teachers and thus more positive developmental and school outcomes. 
Given the results of this research, the assumptions about the contribution of temperament dimensions and teacher-pupil interaction in explaining self-esteem and school success in pupils are partially confirmed. The results confirm the assumptions of the model of Eisenberg et al. (2010) on the role of the quality of teacher-pupil interaction in the relationship between effortful control (self-control in this case) and school success (but also self-esteem). Part of the differences in self-esteem and school success could be attributed to pupil temperament (direct contribution) and part to the indirect contribution through teacher-pupil interaction quality. Therefore, the compatibility of pupil temperament and teacher behaviour is important, since pupils adapt better to school requirements, are more motivated, and have higher self-esteem and better academic achievement when interactions are positive. The tested models of the relationship between temperament and self-esteem and school success through teacher-pupil interaction quality in these two samples did not differ significantly. The differences found, especially the differences in sociodemographic characteristics and potential differences in socialisation in these two samples, may indicate the impact of the broader context. The main contribution of the research conducted is the confirmation of the mediating role of teacher proximity in the relationship of student self-control to self-esteem and school success. Future research should continue to explore the role of teacher characteristics and other components of teacher interaction (e.g., teaching methods, leadership styles, etc.) in the relationship between student characteristics and learning outcomes.

\section{REFERENCES}

Adams, G. R., \& Ryan, A. (2005). The family-school relationships model: Parental influences on school success. In M. Kane (Ed.), Contemporary issues in parenting. Nova Publishing. https://citeseerx.ist.psu. edu/viewdoc/download?doi=10.1.1.616.5858\&rep=rep1\&type $=$ pdf

Ahadi, S. A., Rothbart, M. K., \& Ye, R. (1993). Children's temperament in the US and China: Similarities and differences. European Journal of Personality, 7(5), 359-377. https://doi.org/10.1002/per.2410070506 Al-Hendavi, M. (2013). Temperament, school adjustment, and school achievement: Existing research and future directions. Educational Review, 65(2), 177-205. https://doi.org/10.1080/00131911.2011.648371

Beyazkurk, D., \& Kesner, J. E. (2005). Teacher-child relationships in Turkish and United States schools: Cross-cultural study. International Educational Journal, 6(5), 547-554. https://citeseerx.ist.psu.edu/viewdoc/download?doi=10.1.1.557.542\&rep=rep1\&type $=$ pdf

Bronfenbrenner, U., \& Morris, P. A. (2006). The bioecological model of human development. In R. M. Lerner (Ed.), Handbook of child psycho- 
DRUŠ. ISTRAŽ. ZAGREB GOD. 30 (2021), BR. 3, STR. 509-531

ŠIMIĆ ŠAŠIĆ, S. ET AL.: THE MEDIATING ROLE... logy, Theoretical models of human development (6th ed., pp. 793-828). Wiley Online Library. https://doi.org/10.1002/9780470147658.chpsy0114 Brown, J. D., \& Marshall, M. A. (2006). The three faces of self-esteem. In M. Kernis (Ed.), Self-esteem: Issues and answers (pp. 4-9). Psychology Press. https://faculty.washington.edu/jdb/448/448articles/kernis.pdf

Brown, T. A. (2006). Confirmatory factor analysis for applied research. Guilford. https://doi.org/10.1198/tas.2008.s98

Chan, Y. M. (2000). Self-esteem: A cross-cultural comparison of British-Chinese, white British and Hong Kong Chinese children. Educational Psychology, 20(1), 59-74. https://doi.org/10.1080/014434100110380 Cornelius-White, J. (2007). Learner-centered teacher-student relationships are effective: A meta-analysis. Review of Educational Research, 77(1), 113-143. https://doi.org/10.3102/003465430298563

Croatian Bureau of Statistics. http://www.dzs.hr (25. 3. 2017.)

Darling, N., \& Steinberg, L. (1993). Parenting style as context: An integrative model. Psychological Bulletin, 113(3), 487-496. https://doi.org/ 10.1037/0033-2909.113.3.487

den Brok, P., \& Levy, J. (2005). Teacher-student relationships in multicultural classes: Reviewing the past, preparing the future. International Journal of Educational Research, 43(1-2), 72-88. https://doi.org/ 10.1016/j.ijer.2006.03.007

Duckworth, A. L., \& Allred, K. M. (2012). Temperament in the classroom. In R. L. Shiner \& M. Zentner (Eds.), Handbook of temperament (pp. 627-644). Guilford Press.

Eisenberg, N., Valiente, C., \& Eggum, N. D. (2010). Self-regulation and school readiness. Early Education and Development, 21(5), 681698. https://doi.org/10.1080/10409289.2010.497451

Ellis, L. K., \& Rothbart, M. K. (2001). Revision of the Early Adolescent Temperament Questionnaire. Poster presented at the 2001 Biennial Meeting of the Society for Research in Child Development, in Minneapolis, Minnesota.

Eng, S., Kanitkar, K., Cleveland, H. H., Herbert, R., Fischer, J., \& Wiersma, J. D. (2008). School achievement differences among Chinese and Filipino American pupils: Acculturation and the family. Educational Psychology, 28(5), 535-550. https://doi.org/10.1080/014434 10701861308

Gaias, L. M., Räikkönen, K., Komsi, N., Gartstein, M. A., Fisher, P. A., \& Putnam, S. P. (2012). Cross-cultural temperamental differences in infants, children, and adults in the United States of America and Finland. Scandinavian Journal of Psychology, 53(2), 119-128. https://doi. org/10.1111/j.1467-9450.2012.00937.x

Hamre, B. K., \& Pianta, R. C. (2006). Pupil-teacher relationships. In G. G. Bear \& K. M. Minke (Eds.), Children's needs III (pp. 49-60). National Association of School Psychologist.

Heinonen, K., Räikkönen, K., Keskivaara, P., \& Keltikangas-Järvine, L. (2002). Difficult temperament predicts self-esteem in adolescence. European Journal of Personality, 16(6), 439-455. https://doi.org/10.1002/ 
DRUŠ. ISTRAŽ. ZAGREB GOD. 30 (2021), BR. 3, STR. 509-531

ŠIMIĆ ŠAŠIĆ, S. ET AL.: THE MEDIATING ROLE...
Hernández, M. M., Valiente, C., Eisenberg, N., Berger, R., Spinrad, T. L., Van Schyndel, S. K., Silva, K. M., Southworth, J., \& Thompson, M. S. (2017). Elementary students' effortful control and academic achievement: The mediating role of teacher-student relationship quality. Early Child Research Quarterly, 40, 98-109. https://doi.org/10.1016/j. ecresq.2016.10.004

Hintsanen, M. H. M., Alatupa, S., Pullmann, H., Hirstiö-Snellman, P., \& Keltikangas-Järvinen, L. (2010). Associations of self-esteem and temperament traits to self-esteem and teacher-reported social status among classmates. Scandinavian Journal of Psychology, 51(6), 488-494. https://doi.org/10.1111/j.1467-9450.2010.00820.x

Hu, L., \& Bentler, P. M. (1999). Cutoff criteria for fit indexes in covariance structure analysis: Conventional criteria versus new alternatives. Structural Equation Modeling, 6(1), 1-55. https://doi.org/10.1080/ 10705519909540118

Ibrahimović, N. (2015). Osnovnoškolsko i srednjoškolsko obrazovanje u BiH (trenutno stanje i preporuke za reforme) [Primary and secondary education in BEH (the current situation and recommendations for reforms)]. Eu-Monitoring.ba. https://eu-monitoring.ba/site/wp-content/uploads/ 2015/06/Obrazovanje_Izvjestaj_Namir_Ibrahimovic.pdf (28. 1. 2021.)

Klarin, M., Proroković, A., \& Šimić Šašić, S. (2010). Obiteljski i vršnjački doprinos donošenju odluka iz raznih sfera života $u$ adolescenata - kroskulturalna perspektiva [Family and peer contribution to decision-making in different aspects of life for adolescents - Cross-cultural perspective]. Društvena istraživanja, 19(3), 547-559. https://hrcak. srce.hr/index.php?show $=$ clanak\&id_clanak_jezik $=84310$

Klarin, M., Šimić Šašić, S., \& Proroković, A. (2012a). The contribution of family and peer interaction to the understanding of self-esteem in adolescents - gender and cultural similarities and differences. International Journal of Humanities and Social Science, 2(21), 1-12. http:// www.ijhssnet.com/journals/Vol_2_No_21_November_2012/1.pdf

Klarin, M., Pororoković, A., Šimić Šašić, S., \& Arnaudova, V. (2012b). Some characteristics of social interactions among adolescents in Croatia, Bosnia and Herzegovina, and Macedonia. Psychology Research and Behavior Management, 5, 163-172. https://doi.org/10.2147/PRBM.S 36389

Klein, H. A. (1992). Temperament and self-esteem in late adolescence. Adolescence, 27(107), 689-694.

Levy, J., Creton, H., \& Wubbels, T. (1993). Perceptions of interpersonal teacher behavior. In T. Wubbels \& J. Levy (Eds.), Do you know what you look like? (pp. 26-40). The Folmer Press.

Macuka, I. (2012). Upitnik temperamenta u ranoj adolescenciji [Temperament in early adolescence questionnaire]. In A. Proroković, V. Ćubela Adorić, Z. Penezić, \& I. Tucak Junaković (Eds.), Zbirka psihologijskih skala i upitnika VI. [Collection of psychological scales and questionnaires VI.] (pp. 77-85). Department of Psychology, University of Zadar.

Martin, A. (2014). Interpersonal relationships and pupil's academic and non-academic development. In D. Zandvliet, P. Den Brok, T. 
DRUŠ. ISTRAŽ. ZAGREB GOD. 30 (2021), BR. 3, STR. 509-531

ŠIMIĆ ŠAŠIĆ, S. ET AL.: THE MEDIATING ROLE...
Mainhard, \& J. van Tartwijk (Eds.), Interpersonal relationships in education: From theory to practice (pp. 9-24). Sense Publishers. https://doi. org/10.1007/978-94-6209-701-8_2

McClowry, S. G., Rodriguer, E. T., Tam is-LeMonda, C. S., Spellmann, M. E., Carlson, A., \& Snow, D. L. (2013). Teacher/pupil interaction and classroom behavior: The role of pupil temperament and gender. Journal of Research in Childhood Education, 27(3), 283-301. https://doi. org/10.1080/02568543.2013.796330

McMullin, J. A., \& Cairney, J. (2004). Self-esteem and the intersection of age, class, and gender. Journal of Aging Studies, 18(1), 75-90. https:// doi.org/10.1016/j.jaging.2003.09.006

Muthen, L. K., \& Muthen, B. O. (1998-2010). MPlus user guide. Sixth Edition. Muthen \& Muthen.

Nelson, G. (1984). The relationship between dimensions of classroom and family environments and the self-concept, satisfaction and achievement of grade 7 and 8 students. Journal of Community Psychology, 12(3), 276-287. https://doi.org/10.1002/1520-6629(198407)12:3 $<276$ ::AID-JCOP2290120311>3.0.CO;2-6

OECD (2014). PISA 2012 Results in Focus: What 15-year-olds know and what they can do with what they know. OECD. https://www.oecd.org/ pisa/keyfindings/pisa-2012-results-volume-I.pdf

Puhalo, S. (2005). Povezanost etničkog identiteta i individualističkih i kolektivističkih vrijednosnih orijentacija mladih u Bosni i Hercegovini [The relationship between ethnic identity and individualistic and collectivist value orientations of young people in Bosnia \& Herzegovina]. In V. Turjačanin \& Đ. Čekrlija (Eds.), Ličnost $i$ društvo II. Etnički, državni i evropski identitet [Personality and society: Ethnic, state and European identities] (pp. 113-131). Friedrich Ebert Stiftung Foundation.

Radin, F. (2002). Vrijednosne hijerarhije i strukture [Value hierarchies and structures]. In V. Ilišin \& F. Radin (Eds.), Mladi uoči trećeg milenija [Young people on the eve of the third millennium] (pp. 47-77). Institute for Social Research in Zagreb.

Robins, R. W., Donnellan, M. B., Widman, K. F., \& Conger, R. D. (2010). Evaluating the link between self-esteem and temperament in Mexican origin early adolescents. Journal of Adolescence, 33(3), 403410. https://doi.org/10.1016/j.adolescence.2009.07.009

Roorda, D. L., Koomen, H. M. Y., Spilt, J. L., \& Oort, F. J. (2011). The influence of affective teacher-student relationships on students' school engagement and achievement: A meta-analytic approach. Review of Educational Research, 81(4), 493-529. https://doi.org/10.3102/00346543 11421793

Rothbart, M. K. (2004). Commentary: Differentiated measures of temperament and multiple pathways to childhood disorders. Journal of Clinical Child and Adolescent Psychology, 33(1), 82-87. https://doi.org/ 10.1207/S15374424JCCP3301_8

Rothbart, M. K. (2007). Temperament, development, and personality. Current direction in psychological science, 16(4), 207-212. https://doi.org/ 10.1111/j.1467-8721.2007.00505.x 
DRUŠ. ISTRAŽ. ZAGREB GOD. 30 (2021), BR. 3, STR. 509-531

ŠIMIĆ ŠAŠIĆ, S. ET AL.: THE MEDIATING ROLE...
Rothbart, M. K., \& Bates, J. E. (2006). Temperament. In R. Lerner \& W. Damon (Eds.), Handbook of child psychology: Theoretical models of human development (6th ed., pp. 99-166). John Wiley \& Sons Inc.

Rudasill, K. M. (2011). Child temperament, teacher-child interaction, and teacher-child relationships: A longitudinal investigation from first to third grade. Early Childhood Research Quarterly, 26(2), 147-156. https://doi.org/10.1016/j.ecresq.2010.07.002

Rudasill, K. M., \& Rimm-Kaufman, S. (2009). Teacher-child relationship quality: The roles of child temperament and teacher-child interaction. Early Childhood Research Quarterly, 24(2), 107-120. https://doi. org/10.1016/j.ecresq.2008.12.003

Statistics Agency of B\&H. http://www.bhas.ba (25. 3. 2017.)

Šimić Šašić, S. (2012). Kvaliteta interakcije nastavnika i učenika na različitim razinama obrazovanja [The quality of interaction between teachers and students at different levels of education]. (Unpublished doctoral dissertation). Faculty of Humanities and Social Science in Zagreb, Croatia.

Šimić Šašić, S. (2017). Doprinos učeničkoga temperamenta i interpersonalnoga ponašanja nastavnika $u$ objašnjenju samopoštovanja i školskoga uspjeha učenika [The contribution of student temperament and teacher interpersonal behavior in explaining student self-esteem and school success]. Školski vjesnik, 66(3), 403-422. https:// hrcak.srce.hr/index.php?show $=$ clanak\&id_clanak_jezik $=285255$

Šimić Šašić, S., \& Klarin, M. (2014). Horizontalne i vertikalne dimenzije individualizma i kolektivizma u Hrvatskoj i Bosni i Hercegovini [Horizontal and vertical dimensions of individualism and collectivism in Croatia and Bosnia \& Herzegovina]. Paper presentation. 19th Psychology Days in Zadar, Zadar, Croatia.

Tadić, B. (2019). Kretanje broja i prostorni razmještaj Hrvata u BiH od Prooga svjetskog rata [Population trends and spatial distribution of Croats in Bosnia and Herzegovina since World War I]. Graduate thesis, University of Zadar.

Tashakkori, A. (1993). Gender, ethnicity, and the structure of self-esteem: An attitude theory approach. Journal of Social Psychology, 133(4), 479-488. https://doi.org/10.1080/00224545.1993.9712172

Teglasi, H., Cohn, A., \& Meshbesher, N. (2004). Temperament and learning disability. Learning Disability Quarterly, 27(1), 9-20. https://doi.org/ $10.2307 / 1593628$

Valiente, C. E., Swanson, J. A. I., \& Eisenberg, N. (2012). Linking students' emotions and academic achievement: When and why emotions matter. Child Development Perspectives, 6(2), 129-135. https://doi.org/ 10.1111/j.1750-8606.2011.00192.x

Vizek-Vidović, V., \& Kuterovac-Jagodić, G. (1996). Self-worth scale for children. School Based Health and Peace Initiative: Trauma, healing, and peaceful problem solving (Evaluation Report). Unicef Office for Croatia, CARE, and McMaster University Project.

Wubbels, T., \& Brekelmans, M. (2005). Two decades of research on teacher-student relationships in class. International Journal of Educational Research, 43(1-2), 6-24. https://doi.org/10.1016/j.ijer.2006.03.003

Wubbels, T., Creton, H., Levy, J., \& Hooymayers, H. (1993). The model for interpersonal teacher behavior. U T. Wubbels \& J. Levy (Eds.), Do you know what you look like? (pp 11-26). The Falmer Press. 
DRUŠ, ISTRAŽ. ZAGREB GOD. 30 (2021), BR. 3, STR. 509-531

ŠIMIĆ ŠAŠIĆ, S. ET AL.: THE MEDIATING ROLE...
Posredujuća uloga interakcije između nastavnika i učenika u odnosu temperamenta sa samopoštovanjem i školskim uspjehom učenika

Slavica ŠIMIĆ ŠAŠIĆ, Ana ŠIMUNIĆ, Mira KLARIN Sveučilište u Zadru, Zadar, Hrvatska

Cilj ovog istraživanja bio je ispitati posredujuću ulogu interakcije između nastavnika i učenika u odnosu između temperamenta i samopoštovanja te školskog uspjeha kod učenika viših razreda osnovne škole na uzorku učenika iz Hrvatske i Bosne i Hercegovine. Djelomično su potvrđene pretpostavke o doprinosu dimenzija temperamenta (samokontrole i negativne afektivnosti) i nastavničke interakcije (utjecaja i blizine) u objašnjenju samopoštovanja i školskog uspjeha učenika. Slični odnosi među mjerenim varijablama potvrđeni su na oba uzorka učenika. Samokontrola, negativna afektivnost i nastavnička blizina izravno su predviđale samopoštovanje, dok je samokontrola neizravno pridonosila samopoštovanju preko nastavničke blizine. Školskom uspjehu izravno su pridonosile samokontrola i nastavnička blizina, a značajan je bio i neizravni doprinos samokontrole na školski uspjeh preko nastavničke blizine. Rezultati istraživanja pokazuju važnost izravnoga doprinosa temperamenta samopoštovanju i školskom uspjehu učenika, ali i neizravnog preko kvalitete nastavničke interakcije.

Ključne riječi: interakcija između nastavnika i učenika, temperament, samopoštovanje, školski uspjeh

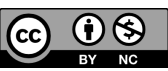

Međunarodna licenca / International License:

Imenovanje-Nekomercijalno / Attribution-NonCommercial 